\title{
Compliance with Hand Hygiene Among Healthcare Workers in Preventing Healthcare Associated Infections - A Systematic Review
}

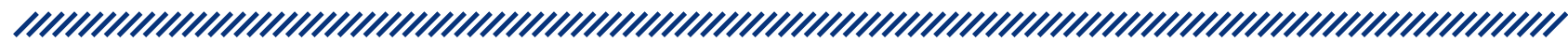

1 Ema Buković

2 Biljana Kurtović

2,3 Cecilija Rotim

${ }^{2,4}$ Vesna Svirčević

${ }^{2,5}$ Adriano Friganović

2,6 Damir Važanić

1 Graduate nursing student, School of Medicine University of Zagreb, Croatia

2 University of Applied Health Sciences, Zagreb, Croatia

3 Andrija Stampar Teaching Institute of Public Health, Zagreb, Croatia

4 Department of Neurosurgery, University Hospital Centre Sestre milosrdnice, Zagreb, Croatia

5 Department of Anaesthesiology and Intensive Medicine, University Hospital Centre Zagreb, Zagreb, Croatia

6 Croatian Institute of Emergency Medicine, Zagreb, Croatia

\section{Summary}

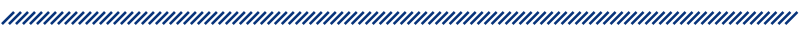

Introduction: Healthcare associated infections (HCAls) represent a major public health issue. In Europe, 37000 patients are affected annually by some sort of HCAl. HCAls are preventable, and hand hygiene is an important measure in their prevention. During daily clinical practice, hands of healthcare workers (HCWs) are exposed to surfaces, various substances and objects; therefore, proper hand hygiene is the first step in preventing microorganism transmission.

Aim: To determine the HCWs hand hygiene compliance with the guidelines of the World Health Organization through a systematic review of literature.

Methods: A systematic review of literature based on the PRISMA statement guidelines using the PubMed data- base in a search for articles that evaluate the hand hygiene compliance among HCWs.

Results: Six articles were taken into consideration by the availability of full-text articles and years of publication between 2010 and 2020. Results showed that compliance rate was the highest in studies that implemented World Health Organisation's Multimodal Hand Hygiene Improvement Strategy or its modifications.

Conclusion: The multimodal approach, as World Health Organisation's multimodal strategy or its local modifications, has been shown as the best approach addressing the problem of hand hygiene compliance. Further areas for research include finding a better method of measuring compliance, technology-driven solutions for both delivery of alcohol-based handrub and monitoring of its use, a greater focus on evaluating proper hand hygiene techniques, and insuring longer-term programs of training and education to achieve the best effectiveness of hand hygiene compliance among HCWs.

Keywords: hand hygiene, World Health Organisation, compliance rate, healthcare workers

Article received: 10.12.2020.

Article accepted: 15.01.2021.

https://doi.org/10.24141/1/7/1/6

\section{Corresponding author}

Ema Buković

A: Kokinačkih žrtava 9, Bjelovar, Croatia

E-mail:emabukovic33@gmail.com

T: +385919540486 


\section{Introduction}

Healthcare associated infections (HCAls) are the world's major healthcare issue. They are defined as infections acquired in hospital, or some other healthcare institution, that appear 48 hours after being admitted. The US Center for Disease Control and Prevention identifies that nearly 1.7 million of hospitalized patients annually acquire some sort of $\mathrm{HCAl}$ and that more than 98,000 of these patients (one in 17) die due to HCAls. ${ }^{1}$ On the other hand, the European Center for Disease Prevention and Control (ECDC) estimates that every year 4,131,000 patients are affected by a HCAl and that, on average, 37,000 patients die from it. HCAls cause prolonged hospital stay, disability, increased resistance of microorganisms to antimicrobials, additional financial burden for health systems, and increased mortality. They also represent a great psychological burden for the patient, their family and healthcare workers while prolonged hospital stay is frequently related to diminished healthcare quality in the entire health system. ${ }^{2}$

HCAls incidence can be prevented, and hand hygiene is one of the essential prevention measures. Healthcare workers play a vital role in preventing the spread of infections. During daily clinical practice, hands of healthcare workers touch various surfaces, substances and objects, food, waste, skin, mucosa, bodily fluids and their own body. Thus, the total number of hand exposures of healthcare workers can reach as many as several tens of thousands per day. With each contact between hands and various surfaces there is a two-way exchange of microorganisms between hands and the objects that were touched. Consequently, the hand transient flora continuously changes. In such a way, microorganisms can spread through the hospital environment in a matter of hours. Proper and effective hand cleansing can prevent microorganism transmission from surface $A$ to surface $B$ if executed before hand transition from one surface to another. ${ }^{3}$ However, the question arises as to what the overall hand hygiene compliance is among healthcare professionals. Studies by the World Health Organization (WHO) have shown that the average compliance rate in the implementation of hand hygiene guidelines is only $38.7 \%{ }^{4}$

In the systematic review of the literature by Naikoba and Hayward, the aim was to determine the effectiveness of interventions aimed at improving hand hygiene of healthcare workers. ${ }^{5}$ Based on the analysis of 21 ar- ticles, they came to the conclusion that only one intervention (for example, strategically placed posters with instructions) is not enough and that a multidimensional approach is needed. This approach should include education, reminders (in the form of posters and written instructions) and feedback, that is, the evaluation of the effectiveness of the implemented interventions. ${ }^{5}$ Furthermore, Erasmus et al. observed the prevalence and correlates of compliance and noncompliance with the guidelines for hand hygiene in hospital environment. The results have shown that direct observation proved to be the best method of measuring compliance or noncompliance with the guidelines; however, it is not entirely certain how reliable an indicator this method is. Specifically, the disadvantage of this study is the Hawthorn effect and the problem of evaluating the then existing international guidelines for maintaining hygiene (before the publication of the WHO guidelines). Notwithstanding the possibility of systematic bias, this is an example of the first review that touched upon the issue of compliance with hand hygiene guidelines, but is limited due to the inclusion of studies conducted prior to the publication of the World Health Organization guidelines. ${ }^{6}$

In line with the aim of solving the problem of evaluating and measuring hand hygiene compliance rate, and generally choosing the best approach, in 2009 the WHO published guidelines for hand hygiene in healthcare institutions. The guidelines include indications for hand hygiene, hand hygiene technique, surgical hand preparation, selection of hand hygiene agents, skin and nail care, use of gloves, hand hygiene for patients and visitors, the role of education, the role of healthcare institutions as well as the government. Furthermore, the guidelines explain the concept of My 5 Moments for Hand Hygiene. The guidelines also identify five elements that need to be implemented and which are a part of the WHO's Multimodal Hand Hygiene Improvement Strategy, and they include system change, that is, the availability of alcohol-based handrub, training and education of healthcare workers, monitoring of hand hygiene practices and feedback, reminders (posters) in the workplace and safe working environment. ${ }^{7,8}$

The aim of this paper is to provide an overview of studies evaluating the effectiveness of compliance with WHO guidelines in developed and developing countries through a systematic review of published studies on the HCWs hand hygiene compliance with the guidelines of the World Health Organization. The second aim is to provide an overview of professional categories and hospital wards with the highest and lowest rates of hand hygiene compliance. 


\section{Methods}

"

The PubMed database was searched using a systematic review of the literature according to the PRISMA guidelines. The keywords were written in English using Boolean operators: hand hygiene OR hand washing AND compliance AND healthcare workers AND World Health Organization. The criteria for the selection of articles (Table 1) and further analysis were: clinical research and observational studies, written in the English language, availability of full text, published in the period from January 2010 to April 2020 and sorted by category "best match".

\begin{tabular}{|c|c|c|}
\hline $\begin{array}{c}\text { Selection } \\
\text { criteria }\end{array}$ & $\begin{array}{l}\text { Inclusion } \\
\text { criteria }\end{array}$ & $\begin{array}{c}\text { Exclusion } \\
\text { criteria }\end{array}$ \\
\hline Type of study & $\begin{array}{c}\text { Original research, } \\
\text { type: clinical trial } \\
\text { and observation } \\
\text { study }\end{array}$ & $\begin{array}{c}\text { review articles } \\
\text { and systematic } \\
\text { reviews }\end{array}$ \\
\hline Keywords & $\begin{array}{l}\text { „hand hygiene OR } \\
\text { hand washing" } \\
\text { „compliance“ } \\
\text { "healthcare } \\
\text { workers“ } \\
\text { „world health } \\
\text { organization“ }\end{array}$ & $\begin{array}{c}\text { „intensive care“ } \\
\text { „emergency } \\
\text { medical service“ } \\
\text { „primary care, } \\
\text { nursing homes“ } \\
\text { „glove usage“ } \\
\text { „behavior" } \\
\text { „dental students“ } \\
\text { „newborns" }\end{array}$ \\
\hline $\begin{array}{c}\text { Year of } \\
\text { publication }\end{array}$ & $2010-2020$ & before 2010 \\
\hline Language & English & All other \\
\hline
\end{tabular}

Database search by keywords yielded 94 articles, and through further use of inclusion criteria, 23 articles were found. By applying exclusion criteria, the articles published before 2010, articles narrowly focused on one area of research (e.g., intensive care, primary care, emergency services, neonatal care), or only one hand hygiene technique (e.g., only the use of gloves, or, only the use of alcohol-based handrub) were excluded from consideration. Articles that, as the primary focus of the research, were influenced by behavioral psychology and workload that affects the performance of hand hygiene were also excluded. The relevance of all identified studies was also assessed based on the title and the abstract. After applying the inclusion and exclusion criteria, 6 articles were selected for more detailed analysis.

\section{Results}

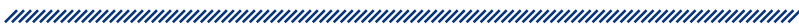

The articles that were analyzed include original research from different parts of the world - Iran, the Netherlands, Ethiopia, Switzerland, Ghana and Malawi and were published at different time periods - 2013, 2015, 2016,2017 , and 2019. An overview of the articles finally selected for the analysis is shown using the Prisma 2009 Flow diagram. (Figure 1)

Farhoudi et al. (2016) conducted a quasi-experimental study on 54 hospital wards whose aim was to assess the effect of implementing the WHO Multimodal Hand Hygiene Improvement Strategy. The whole project consisted of 5 steps: [1] facility preparedness, [2] baseline evaluation, [3] implementation, [4] follow-up evaluation, and [5] further planning and review cycles. Wards such as the internal medicine ward, emergency ward, surgical ward, pediatrics and intensive care unit were included in the study. Following the strategy of the WHO, in step one human and financial resources were attained, key leadership of the project was identified, strategy was developed, washbasins equipped with soap were placed by the beds (one washbasin for 6 beds) and alcohol-based handrub wall dispensers were placed outside of each room (they were not available while providing care). Step two, or baseline evaluation, was performed by two doctors who specialized in infection control. The training for the doctor observers included a Power Point presentation and video clips. They were also acquainted with the important elements of the WHO Hand Hygiene Technical Reference Manual. ${ }^{8}$ The second part of the evaluation was conducted on hospital wards where health workers were observed by the trained doctor observers.

Hand hygiene compliance rate is defined by the ratio between hand hygiene actions and hand hygiene opportunities. The health workers were aware of being observed which increased the possibility of systematic bias. With the aim of observing the most need for hand hygiene opportunities, observation was performed during therapy application. Data was collected in the period of 3-4 weeks and the average number of observed hygiene opportunities was 16 per ward. Furthermore, in step three alcoholbased handrub dispensers were placed beside each bed, there was greater availability of paper towels and posters showing My 5 Moments for Hand Hygiene sequence. Nurses had to attend education programs in infection prevention with the emphasis on hand hygiene twice a year. 


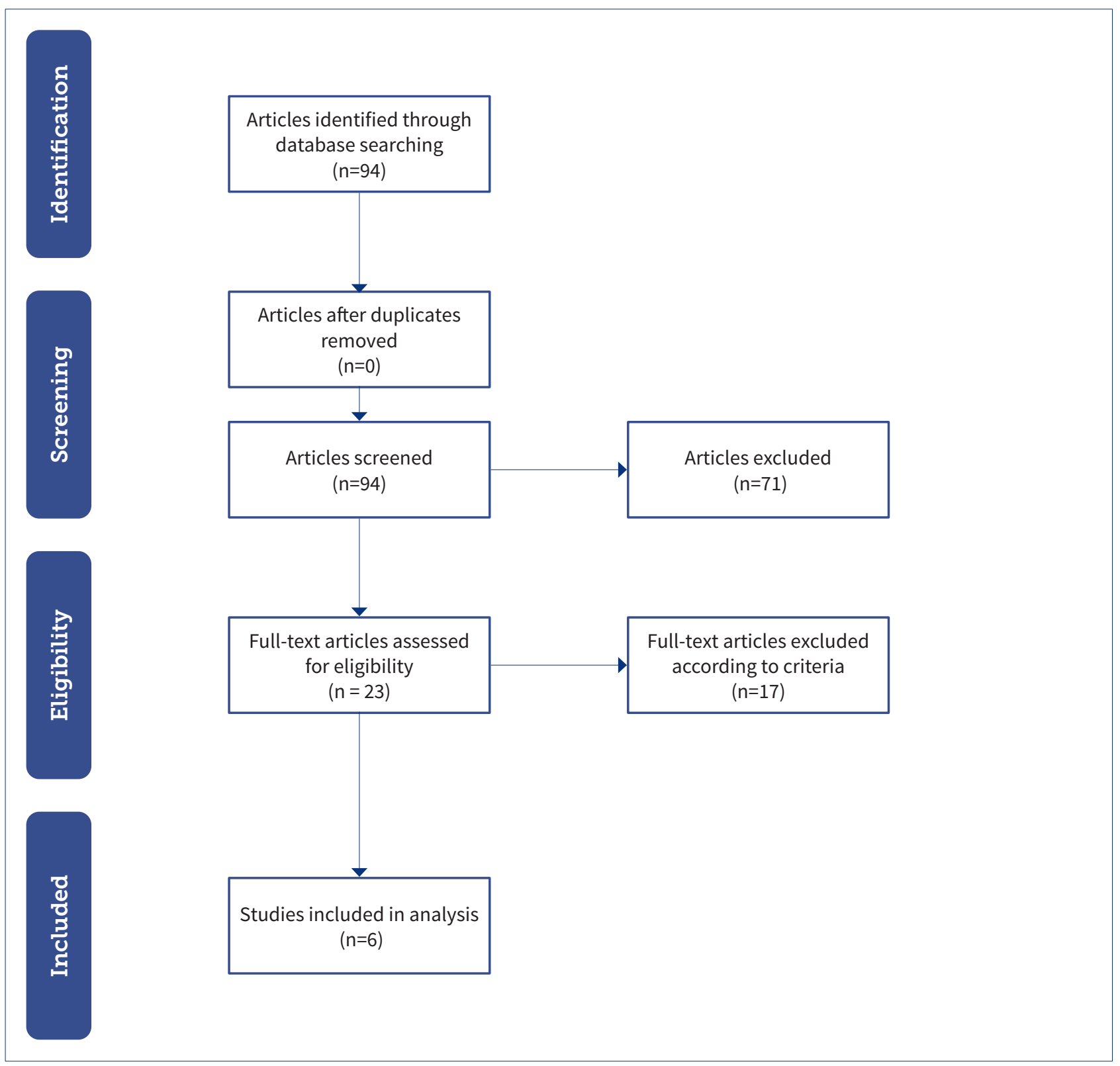

\section{Slika 1. Flow diagram for systematic review of literature}

The education was also provided once a year for medical students, prior to their clinical training, and for doctors. Newly employed nurses had to take an exam on infection prevention. Additionally, education programs in intensive care units also put emphasis on hand hygiene due to their lowest compliance rate. After twelve months, follow-up evaluation to assess the program effectiveness was performed. Data was analyzed using SPSS software and pvalue was less than $0.05(p<0.05)$ which was considered statistically significant. Before the implementation of the strategy, there was a total of 255 hand hygiene opportunities and 76 hand hygiene actions were recorded. After the implementation, out of 193 hand hygiene opportunities, there were 137 hand hygiene actions, which increased the compliance rate from 29.8 to $70.98 \%$. The most representative were the results of nurses, whose hand hygiene compliance rate increased from $29.6 \%$ to $72.7 \%, p<0.001$. In addition, the nurses compliance rate from different wards has changed, with the biggest change in the surgical ward with the increase from $0 \%$ to $64.7 \%$, and the emergency ward with the increase from $16 \%$ to $75 \%$. The use of alcohol-based handrub has increased from $6.3 \%$ to $66.3 \%$ making it a more popular method of hand hygiene than hand washing. ${ }^{9}$ 


\section{Table 2. Overview of the articles finally selected}

\begin{tabular}{|c|c|c|c|}
\hline ARTICLE & AIM & RESEARCH DESIGN AND METHOD & RESULTS \\
\hline $\begin{array}{c}\text { Farhoudi et } \\
\text { al. }{ }^{9} \\
\text { Iran }\end{array}$ & $\begin{array}{l}\text { To assess the effect } \\
\text { of implementing the } \\
\text { WHO Multimodal } \\
\text { Hand Hygiene } \\
\text { Improvement } \\
\text { Strategy at the } \\
\text { tertiary teaching } \\
\text { hospital. }\end{array}$ & $\begin{array}{l}\text { Quasi-experimental study conducted in the } \\
\text { period between June } 2014 \text { and June } 2015 . \\
54 \text { hospital wards in total. } \\
\text { Methodology: } \\
\text { Components of WHO Multimodal Hand Hygiene } \\
\text { Improvement Strategy }{ }^{7}\end{array}$ & $\begin{array}{l}\text { Increase of the compliance rate } \\
\text { after implementing the multimodal } \\
\text { strategy from } 29.8 \% \text { to } 90.98 \% \\
\left.\quad p<0.05^{*}, \text { (SPSS system }\right) \\
{ }^{*}(p<0.05) \text { statistically significant }\end{array}$ \\
\hline $\begin{array}{l}\text { van Dijk et } \\
\qquad \begin{array}{c}\text { al. } \\
\text { The }\end{array} \\
\text { Netherlands }\end{array}$ & $\begin{array}{l}\text { To evaluate the } \\
\text { effects of a friendly } \\
\text { competition in hand } \\
\text { hygiene compliance } \\
\text { between } 9 \text { public } \\
\text { hospitals and } 1 \\
\text { rehabilitation centre. }\end{array}$ & $\begin{array}{l}\text { Observational study from } 2014 \text { to } 2016 \text {, at } \\
\qquad 6 \text {-month intervals. } \\
120 \text { hospital wards in total. } \\
\text { Methodology: } \\
\text { Roll Up Your Sleeves program consisting of } \\
5 \text { elements and modifications of the WHO } \\
\text { multimodal strategy. }\end{array}$ & $\begin{array}{l}\text { At the end of the study the average } \\
\text { compliance rate was } 51.4 \% \text {. A } \\
\text { statistically significant increase of } \\
\quad 8.5 \%,(p<0.001)^{*} \\
{ }^{*}(p<0.001) \text { statistically significant }\end{array}$ \\
\hline $\begin{array}{l}\text { Kolola et } \\
\text { al. }^{11} \\
\text { Ethiopia }\end{array}$ & $\begin{array}{l}\text { To evaluate the hand } \\
\text { hygiene compliance } \\
\text { among healthcare } \\
\text { workers } \\
\text { in Debre Berhan } \\
\text { referral hospital. }\end{array}$ & $\begin{array}{l}\text { A 24-hour observational study. } \\
5 \text { different wards, } 307 \text { healthcare workers } \\
\text { included in the study. } \\
\text { Methodology: } \\
\text { A standardized WHO's hand hygiene } \\
\text { observation tool for direct observation. }{ }^{12}\end{array}$ & $\begin{array}{l}\text { Averagely low compliance rate, } 22 \% \text {. } \\
\text { There are no significant differences } \\
\text { in the compliance rates between the } \\
\text { wards. There is a higher compliance } \\
\text { rate on the peadiatric ward and } \\
\text { neonatal intensive care unit ( } 26.5 \% \text { i } \\
27.5 \%) \text {. }\end{array}$ \\
\hline $\begin{array}{l}\text { Tschudin- } \\
\text { Sutter et } \\
\text { al. }^{12} \\
\text { Switzerland }\end{array}$ & $\begin{array}{l}\text { To evaluate the } \\
\text { healthcare workers } \\
\text { compliance with } \\
\text { the guidelines on } \\
\text { proper hand hygiene } \\
\text { technique which } \\
\text { consists of } 6 \text { steps. }\end{array}$ & 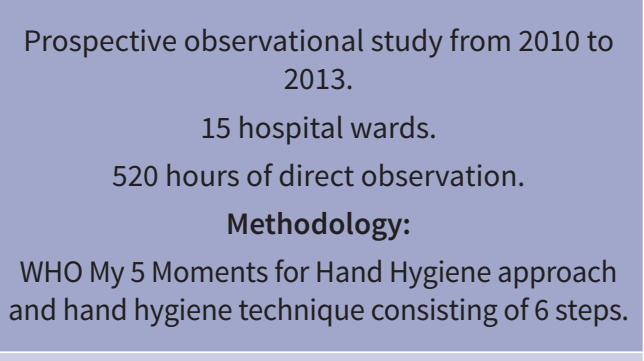 & $\begin{array}{l}\text { High hand hygiene compliance rate, } \\
93.2 \% \text {. The highest compliance in the } \\
\text { intensive care unit, } 100 \%, p<0.001 \\
\text { Low compliance rate with the hand } \\
\text { hygiene technique ( } 6 \text { steps), } 8.5 \% \text {. } \\
\text { The compliance rate decreased } \\
\text { in proportion to the increase in } \\
\text { employment duration. }\end{array}$ \\
\hline $\begin{array}{c}\text { Yawson et } \\
\text { al. }^{13} \\
\text { Ghana }\end{array}$ & $\begin{array}{l}\text { To assess the } \\
\text { availability of } \\
\text { handrubs and hand } \\
\text { hygiene compliance } \\
\text { rate among } \\
\text { healthcare workers } \\
\text { in the Korle-Bu } \\
\text { Teaching Hospital. }\end{array}$ & $\begin{array}{l}\text { A cross-sectional, observational study over a } \\
\text { three-week period in September } 2011 . \\
\qquad 15 \text { clinical wards. } \\
\text { Methodology: } \\
\text { Standardized checklist designed by the } \\
\text { Infection Prevention and } \\
\text { Control Unit of the hospital. The checklist is the } \\
\text { adaptation of the WHO Ward Infrastructure Survey. }{ }^{15}\end{array}$ & $\begin{array}{c}\text { Overall low hand hygiene } \\
\text { compliance, } \\
\text { Ranging from } \\
9,2 \% \text { to } 57 \% \text { for doctors and } 9,6 \% \text { to } \\
54 \% \text { for nurses. The compliance rate } \\
\text { was higher on the high-risk wards. }\end{array}$ \\
\hline $\begin{array}{c}\text { Kalata et } \\
\text { al. }^{14} \\
\text { Malavi }\end{array}$ & $\begin{array}{l}\text { To assess the } \\
\text { adherence to hand } \\
\text { hygiene protocol by } \\
\text { doctors and medical } \\
\text { students at Queen } \\
\text { Elizabeth Central } \\
\text { Hospital. }\end{array}$ & $\begin{array}{l}\text { A single-blind observational study in two parts. } \\
\text { First part included the observation of the } \\
\text { respondents, the second part was filling out a } \\
\text { questionnaire. } \\
4 \text { clinical wards, } 56 \text { respondents; } 2 \text { groups } \\
\text { (doctors and medical students) } \\
\text { Methodology: } \\
\text { A standardized WHO's hand hygiene } \\
\text { observation tool for direct observation. }{ }^{12}\end{array}$ & $\begin{array}{l}\text { Doctors demonstrated a higher } \\
\text { rate of hand disinfection }(p<0,05) \text {; } \\
\text { however, compliance rate was very } \\
\text { low and similar in both groups ( } p= \\
\text { 0.2). The compliance rate was } 23,5 \% \text {, } \\
\text { and only } 30 \% \text { of all hand disinfections } \\
\text { were properly executed. }\end{array}$ \\
\hline
\end{tabular}


Van Dijk et al. conducted an observational study with the aim of evaluating the effects of a friendly competition in hand hygiene compliance between 9 public hospitals and 1 rehabilitation centre in the Netherlands. For that purpose they devised a hand hygiene program called Roll Up Your Sleeves based on monitoring and feedback on hand hygiene compliance at 6-month intervals over two years. The program comprised several elements. There was individual e-learning about indications and hand hygiene techniques for nurses and doctors. A free kick-off workshop was conducted in which infection control staff, ward managers and head nurses from every organization involved were acquainted with the implementation strategy, rules, priorities, and goals regarding hand hygiene and the program in question. In order to train the teams a train-the-trainer program was organized for the stakeholders from each organization who were trained to train healthcare workers in their own organization on how to improve hand hygiene on wards. In observer training, infection prevention specialists and other healthcare workers who were trained for observation, were trained to carry out their own internal audits. All education interventions were based on the Hand Hygiene Australia program. ${ }^{15}$ This program is based on the WHO My 5 Moments for Hand Hygiene approach. Observational data was collected during a 2-hour period and at least 3 nurses were being observed. Apart from nurses, doctors and other healthcare workers who were at that moment involved in care were also included in the observation. In the final and most important element, the participants and each organization received a standardized feedback report on hand hygiene compliance results after each round of observation. Healthcare workers were observed in 5 observation rounds total, which were conducted over a 2-year period at 6-month intervals. The hand hygiene compliance rate before the implementation of the program was $42.9 \%$. After implementing the first phase of the program, the e-learning, and the second phase, kick-off workshop, the compliance rate increased for $2,2 \%$ to $45,1 \%$. During the third phase it decreased to $41,2 \%$. In this phase, 3 organizations implemented the workshop and the compliance rate increased again. After observer training in 7 organizations and team training in 2 organizations the compliance rate increased to 53.9\% in the period between September 2014 and May 2015. At the end of the study the average compliance rate for all organizations was $51,4 \%$, which was a statistically significant increase of $8.5 \%(p<0.001)$ (with great variations between the organizations, from $-11.5 \%$ to $+33.3 \%$ ), from the beginning till the end of the study.
Furthermore, the compliance rate differed between the wards as well. There was a low increase in the compliance rate on the surgical wards (only 6.9\%), while on the gynecology wards there was an increase of $20,5 \%$. The neonatal wards had the highest increase of $72,6 \%$. Study limitations come from the fact that the organizations could choose which interventions to implement and in which time period. Besides the necessary interventions of observation and providing feedback, the organizations were allowed to introduce their own interventions (outside the Roll Up Your Sleeves program). This study proves that hand hygiene can be improved outside the framework of a set strategy with strictly defined rules. ${ }^{10}$

In 2017 Kolola et al. conducted a 24-hour observational study based on the guidelines of the WHO hand hygiene observation method for measuring compliance on 5 different wards (medical, surgical, neonatal intensive care unit, paediatric, obstetrics and gynecology). ${ }^{11}$ Observation was conducted during 24 hours in order to minimize the selection bias and the possibility of systemic bias. Data was collected using the standardized WHO's hand hygiene observation tool for direct observation. ${ }^{16}$ Prior to observation, the observers were trained in accordance with the WHO's hand hygiene observation method. Each observer had to separately fill in the observation form while observing the same healthcare worker and the same sequence of providing care. The results were then compared and any differing information was discussed. The observation process was repeated until there was concordance in terms of the number of hand hygiene opportunities and hand hygiene actions. Three nurses directly observed 261 healthcare workers in direct contact with patients or their surroundings, and recorded all hand hygiene opportunities and hand hygiene actions. Healthcare workers were not aware of being observed in order to minimize the Hawthorne effect. According to the WHO recommendation, more than 200 opportunities per ward were observed. During the study a total of 917 hand hygiene opportunities were observed. The overall compliance rate was $22 \%$. The compliance rate for doctors was $20.6 \%, 22.9 \%$ for nurses, $21.2 \%$ for midwives and $23.2 \%$ for other healthcare workers. The neonatal intensive care unit and pediatric ward had the highest rate of compliance, $27,3 \%$ and $26,5 \%$ respectively. The rate of compliance according to the My 5 Moments for Hand Hygiene was lower before patient contact (2.4\%) before the aseptic procedure (3.6\%) and after contact with patient surroundings (3.3\%). Higher level of com- 
pliance was found after exposure to bodily fluid (75.8\%) and after patient contact (42.8\%). Rubbing hands with alcohol-based handrub was performed in 95 (47.0\%) out of 202 hand hygiene actions. The reason for such a low level of hand hygiene compliance was stated to be the lack of implementation of a multimodal strategy for improving hand hygiene. There were no visual reminders in the workplace, and similarly, there was no longterm evaluation and performance feedback on hand hygiene.

Tschudin-Sutter et al. conducted a prospective observational study at one university hospital in Switzerland. ${ }^{12}$ The aim of the study was to assess the healthcare workers compliance with the guidelines on proper hand hygiene technique based on the evaluation of observing guidelines on proper use of handrub which consists of 6 steps. ${ }^{4}$ During the study period from 2010 to 2013 the observation of hand hygiene was observed on 15 hospital wards: 5 medical and 5 surgical wards, 2 emergency ward departments, 2 intensive care units and one bone marrow transplant unit. All observations were performed by 3 trained observers during 520 hours of direct observation. What was observed was the compliance with the My 5 Moments of Hand Hygiene approach. Additionally, the individual steps of hand hygiene technique outlined by the $\mathrm{WHO}^{4}$ were also observed, and they are: (1) rubbing hands palm to palm, (2) palm to palm with interlaced fingers, (3) right palm over left dorsum with interlaced fingers and vice-versa, (4) backs of fingers to opposing palms with fingers interlocked, (5) rotational rubbing of left thumb clasped in right palm and vice versa and (6) rotational rubbing, backwards and forwards with clasped fingers of right hand in left palm and vice versa. Overall, 2,662 hand hygiene opportunities were observed, mostly among nurses (65.3\%), doctors (21.7\%), and other healthcare workers (13\%). The highest compliance rate was observed „after touching the patient"(41.9\%), followed by ,before touching the patient" (31.9\%). In total, compliance rate was 93.2\%. With regards to different wards, the highest compliance rate was observed in intensive care units $(100 \%)$ and emergency wards $(94,8 \%)$, and the lowest compliance rate was observed on surgical wards $(90 \%)$. With different healthcare professions no significant difference were observed and the compliance rate remained high. Nurses had a somewhat higher compliance rate compared to doctors, $93.6 \%$ to $91.5 \%$. Compliance rate with the proper hand hygiene technique (6 steps) was $8.5 \%$, and most of the healthcare workers followed steps 2 and 3. Such relatively low compliance rate decreased in proportion to the increase in employment duration $(p=0.002)$. Even though compliance with hand hygiene opportunities was high, the proper technique of using alcohol-based handrub was used in $<10 \%$ of all hand hygiene opportunities. Young healthcare workers and those employed for shorter time periods more likely followed to all 6 steps of hand hygiene. ${ }^{12}$

In 2013, Yawson et al. construed a cross-sectional, observational study to assess the availability of handrubs and hand hygiene compliance rate among healthcare workers in the Korle-Bu Teaching Hospital in Ghana. ${ }^{13}$ Wards included in the study were: pediatrics, internal medicine, surgery, gynaecology and obstetrics, and central hospital laboratory (venipuncture laboratory). Those 5 wards were chosen based on the clinical services they provide and critical importance of hand hygiene in infection prevention among healthcare workers and patients. Over 3 weeks, healthcare workers including doctors, nurses and laboratory staff, were observed by inconspicuous observers. Data was collected using the standardized checklist designed by the Infection Prevention and Control Unit of the hospital. The checklist is the adaptation of the WHO Ward Infrastructure Survey and is one of the tools to monitor and evaluate hand hygiene and is part of the WHO's multimodal strategy. ${ }^{17} \mathrm{Six}$ observers who had prior training, and who had experience in infection prevention, collected the data. The observers collected data in pairs, in an unobtrusive manner, so that their presence did not affect the work of the observed healthcare workers. Each ward was observed at a different time of day for two days. In order to limit observer bias, every ward was observed by a different pair of observers each day. Hand hygiene compliance was assessed using My 5 Moments for Hand Hygiene. Hand hygiene compliance was considered effective if $50 \%$ or more of the healthcare workers followed the recommended techniques during the observation period. Effective hand hygiene in this study was based on the recommendations from the WHO Hand Hygiene Technical Reference Manual ${ }^{8}$ and it included the use of alcohol-based handrub and washing hands with soap and water. The rate of compliance was measured as a ratio between hand hygiene actions and hand hygiene opportunities. The observed healthcare workers were nurses and doctors. In general, the compliance rate was low. Before examining the patient, the lowest doctor compliance rate was $9,2 \%$ on the pediatric ward compared to the $21.7 \%$ compliance rate as the lowest percentage after examining a patient. Similarly for nurses, the lowest compliance rate was $9.7 \%$ on surgical and 
emergency wards, compared to $22 \%$ compliance rate as the lowest percentage of compliance on the children's emergency ward. Both professions had a higher compliance rate for all 5 moments for hand hygiene at the neonataology intensive care unit. Both doctors and nurses have demonstrated a low compliance rate while being exposed to bodily fluids and while touching mucous membranes. It was observed on all wards that almost all healthcare workers which performed hand hygiene used soap and running water, while the use of alcoholbased handrub was observed on pediatric wards. Out of the observed healthcare workers, less than half used alcohol-based handrub as a hand hygiene method. Overall hand hygiene compliance ranged from $9.2 \%$ to $57 \%$ for doctors and from $9.6 \%$ to $54 \%$ for nurses. ${ }^{13}$

Kalata et al. conducted a single-blind observational study in two parts with the aim of assessing the adherence to hand hygiene protocol by doctors and medical students at Queen Elizabeth Central Hospital in Blantyre in Malawi. ${ }^{14}$ The study was divided into two parts; a single blind study which included the observation of the respondents by trained nurses who filled in a standardized WHO's hand hygiene observation tool; and the second part where respondents filled in a questionnaire. According to the WHO recommendations, hand hygiene effectiveness was defined as completing at least 6 out of 7 steps $(80 \%)$ of the hand hygiene technique when using alcohol-based handrub, or completing at least 8 out of 10 steps $(80 \%)$ of the hand hygiene technique when using soap and water before and after direct contact with patients. The sample consisted of doctors and medical students and the names of the observed participants were randomly selected. The sample size was 116 but only 58 participants were observed. Every ward at the hospital had at least 4 washbasins with soap and at least two wall alcohol-based handrub dispensers near patient beds. Data collection occurred in two stages. Firstly, the study participants were being observed without their knowledge on two ward rounds by trained nurses who monitored hand hygiene using the observation tool. Secondly, each participant was then asked to fill in a participant's questionnaire. The results show that doctors disinfected their hands more often than medical students $(p<0.05)$, but for both groups the effectiveness was similar and also very low $(p=0.2)$. The doctors had a total of 479 disinfection opportunities, with 147 hand disinfections (30.7\%), and only 41 $(27.9 \%)$ effective disinfections. Medical students had 243 disinfection opportunities and performed only 23 (9.5\%) disinfections with only 10 (43.5\%) effective dis- infections. Compliance rate was very low, only $23.5 \%$ compared to $30 \%$ of effective hand disinfections. Effective disinfection implied all protocol hand hygiene steps. There was a statistically significant difference between the professional category and hand hygiene procedure $(p=0.01)$; however, there was no statistically significant difference between the professional category and effective hand hygiene, and between the availability of alcohol-based handrub and hand hygiene activity $(p=0.48)$. The authors stated the following reasons for low hand hygiene compliance rate: forgetfulness ( 9 participants), unavailability of hand disinfectants or soap (9 participants), great workload and too many patients (8 participants), negligence (3 participants) and inadequate placement of the washbasins with soap and disinfectant at remote ends of hospital wards. The main limitation of the study was a small sample size. ${ }^{14}$

\section{Discussion}

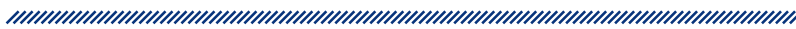

Healthcare associated infections are a major patient safety issue and their surveillance and prevention must be a priority in environments and institutions that advocate for safer healthcare. The impact of healthcare associated infections includes prolonged hospital stays, long-term disability, increased resistance of microorganisms to antimicrobial drugs, high additional financial burden, high costs for patients and their families, and excess mortality. Although the global problem of healthcare associated infections is difficult to fully illustrate, due to difficulties in gathering data, it permeates every healthcare facility and system in the world. Overall estimates state that at any given time this problem affects more than 1.4 million patients worldwide in developed and developing countries. ${ }^{2}$

With the aim of solving this issue, in 2005 as part of the WHO Patient Safety Programme, a First Global Patient Safety Challenge was initiated under the name Clean Care is Safer Care in order to attract international interest and action concerning the critical issue of healthcare associated infections and patient safety and concerning the important role that hand hygiene compliance of healthcare workers has on reducing HCAI rates. In 2009, WHO Patient Safety Programme launched a campaign SAVE LIVES: Clean Your Hands, an initiative that aims 
to ensure a lasting global, regional, national and local interest in hand hygiene in healthcare. In particular, the program reinforces interest in the My 5 Moments for Hand Hygiene approach as a key element in protecting the patient, healthcare worker and healthcare environment from the spread of pathogens and thus reducing the incidence of healthcare associated infections.

Successful and lasting hand hygiene improvement is achieved by applying multiple actions in the fight against various obstacles both in the working systems and in behavior. Based on the evidence and recommendations of the WHO Guidelines on Hand Hygiene in Healthcare, a number of components put together form an effective multimodal strategy for improving hand hygiene. For this reason, it has been proposed that the WHO's multimodal hand hygiene improvement guidelines on hand hygiene in healthcare be transferred into practice, with the help of a wide range of practical tools (implementation tools) ready for use and application. The key components of the strategy are: [1] system change: ensuring that the necessary infrastructure is in place to allow healthcare workers to practice hand hygiene (soap, paper towels, alcohol-based handrub), [2] education: providing regular training on the importance of hand hygiene, based on the My 5 Moments for Hand Hygiene approach, and correct procedures for hand hygiene, for all healthcare workers, [3] evaluation of hand hygiene and infrastructure, along with related perceptions and knowledge of healthcare workers while simultaneously providing feedback on performance and results, [4] reminders in the workplace: encouraging and reminding healthcare workers about the importance of hand hygiene and about the appropriate indications and procedures, and [5] safe working environment: creating an environment and perception that facilitate raising the awareness about patient safety and at the same time guarantee the consideration of hand hygiene improvement as a high priority at all levels, including active participation at the institutional and individual level, the awareness of individual and institutional capacity for change and improvement and partnership with patients. ${ }^{7}$ The implementation of the WHO Multimodal Hand Hygiene Improvement Strategy has proven to be effective in increasing the compliance rate of healthcare workers in performing hand hygiene. This is evidenced by the research of Farhoudi et al. analyzed in this paper, in which the hand hygiene compliance rate improved from $29.8 \%$ to $70.9 \%$. By applying this approach, the compliance rate also increased for all components of My 5 Moments of Hand Hygiene. The effectiveness of the multimodal strategy is supported by the quasi-experimental study by Shen et al. ${ }^{18}$ where the compliance rate in a total of 23 hospital wards improved from $66.2 \%$ to $80.5 \%$, after the implementation of all elements of the strategy. Furthermore, the correctness rate of hand hygiene techniques improved from $47.7 \%$ to $88.3 \%$ after the intervention. The increase in compliance was statistically significant $(p<0.05)$ for all professional categories. ${ }^{18}$ Furthermore, the quasi-experimental study by Allegranzi et al. ${ }^{19}$ on as many as 55 hospital wards in 43 hospitals, showed similar changing results. The overall average compliance rate prior to the interventions increased from $51 \%$ to $67.2 \%$ after the interventions. Changing the system has proven to be one of the most important steps in implementing change in many institutions. Shen et al. also mentioned this problem as one of the factors of reduced hand hygiene. By implementing measures such as increasing the provision of alcohol disinfectants and disposable paper towels and placing posters with instructions on hand hygiene, a significant step towards increasing the compliance rate has begun. This measure has proved particularly crucial, but often problematic to implement in developing countries. ${ }^{18}$ Namely, the results of the analyzed articles by Yawson et al. ${ }^{13}$ and Kalata et al. ${ }^{14}$ support low compliance rate in developing countries. In the study conducted by Yawson et al., alcohol-based disinfectants were available on only 3 wards of the 15 included in the study, and only 7 wards had soap stored in perforated containers (which was the preferred option), while on 7 wards soap was left on or in the washbasin. Basic equipment, such as liquid soap dispenser, was not available on 5 wards. Although 10 wards had a liquid soap dispenser, liquid soap was available for use on only 4 wards. In their research Kalata et al., in the results of the survey conducted among 31 participants, show that the answer for not performing hand hygiene, which was "lack of soap or disinfectant", was present in as many as 9 participants. Allegreanzi et al. in their study, which included developed and developing countries, states that the effect of interventions on hand hygiene compliance was greater in low- and middle-income countries than in high-income countries, and that, as expected, greater hygiene compliance was easier to achieve in low- and middle-income countries. ${ }^{19}$ This certainly demonstrates a positive picture, and that is that with the implementation of simple interventions, such as education and provision of basic resources, we can significantly contribute to improving patient safety, which is certainly a priority in healthcare. The change of the system by a better supply and the preferred use of alcohol-based handrub as one of the techniques of hand hygiene, after the implementation of the WHO strategy, was a key de- 
terminant of practice improvement. ${ }^{20}$ The multimodal strategy is only a framework for improving hand hygiene quality. According to the results of the systematic review, there is a clear difference between studies in which a multimodal strategy (Farhoudi et al.) or its modifications (van Dijk et al.) were applied, as opposed to the other 4 articles in which the compliance rate was evaluated based on the compliance with My 5 Moments for Hand Hygiene approach or proper hand hygiene technique. Developing monitoring programs aimed at evaluating hygiene effectiveness, and not just observing opportunities for its implementation, is especially needed in institutions where the compliance rate is defined as high, but where the compliance with the correct steps of hand hygiene techniques is not observed or assessed. This further raises the question of how much fulfilling all the hygiene opportunities (thus achieving a high rate of compliance) really solves the problem of infections, i.e., transmission of bacteria and microorganisms, and which factors affect the long-term decline in hand hygiene efficiency. Proper hand hygiene training programs should be offered multiple times during professional life to ensure a greater degree of infection protection. ${ }^{20}$ Taking into consideration professional categories and hospital wards, some differences were also observed. The data presented in the analyzed articles related to professional categories lack consistency and uniformity in terms of a more specific definition of the included professional categories. Analyzing the articles, the largest differences in compliance rates were observed between nurses and physicians. Nurses showed a higher compliance rate despite a higher number of hand hygiene opportunities. ${ }^{9,11,14,16}$ Since in most cases nurses make up the largest group of healthcare workers, it is not surprising that the nursing profession is so well represented in these studies and accounts for most of the sample. ${ }^{20}$ Research by Huis et al. (2013), in terms of professional category, focused exclusively on the nursing profession ( $N=2733$ ), and there is no doubt that the results, although primarily intended for the evaluation of the nursing profession, can be significant guidelines for other professional groups ${ }^{21}$ Analyzing hospital wards, the highest compliance rate is visible in intensive care units, more precisely, in neonatology units. This actually speaks in favor of the fact that the highest incidence of healthcare associated infections is actually in the intensive care units. The data show that in these units, $19.5 \%$ of patients had at least one healthcare associated infection, as opposed to an average of $5.2 \%$ incidence of healthcare associated infections on other hospital wards. The ECDC estimates that $5.7 \%$ of patients, or one in 18 patients, that is, 80,000 pa- tients in European hospitals have an infection every day. This confirms that healthcare associated infections remain a major public health problem for patients in the field of acute care in Europe. ${ }^{22}$ In all analyzed articles, the direct observation method was used as the research method. Currently, such "direct observation of participants" is considered the gold standard in measuring hand hygiene compliance. The advantages of such a method are quick identification of potential problems related to staff (e.g., lack of motivation, lack of knowledge), identification of lack of resources and the possibility of error in hand hygiene, and thus easier individual education immediately after monitoring. Furthermore, when analyzing the results, one encounters a psychological phenomenon called the Hawthorn effect, which states that participants increase their effectiveness and resort to more socially desirable behaviors when they know they are being observed. For this reason, when using the direct observation method, the bias factor must be taken into account when collecting data. ${ }^{23} \mathrm{Koff}$ et al. in their research conclude that the electronic device is a more reliable system for monitoring hand hygiene compliance. ${ }^{24}$ Namely, an electronic device called The Sprixx GJ device is an alcohol-based handrub that dispenses $0.75 \mathrm{ml}$ of solution when the piston is activated and it reminds you of performing disinfection every 6 minutes, while recording every performed action. It allows you to document the timestamp for each hand hygiene decontamination (HHDE) event on a digital memory chip, and also allows you to download your hand hygiene actions to the Microsoft Access Database (Microsoft Co., Seattle, WA). The results have shown that the use of the device contributed to significant improvements in compliance with hand hygiene implementation, from an average of $53 \%$ prior to the study to an average of $75 \%$ during the study period. With advances in technology and continuous research into the effectiveness of such devices, it will be possible to replace the direct observation method with similar devices, and it will also be possible to implement newer approaches to measuring compliance in this field of research. ${ }^{24,25}$ The use of alcohol-based handrubs is the gold standard in hand hygiene and its availability is a key factor in hand hygiene improvement. That presents a problem in the developing countries, due to procurement and high cost of these products. To address this problem, the WHO's multimodal strategy offers a guide for local alcohol production in hospital pharmacies or other similar local facilities. Local production is carried out in many healthcare facilities around the world and is carefully monitored and evaluated by the WHO. ${ }^{26}$ 


\section{Conclusion}

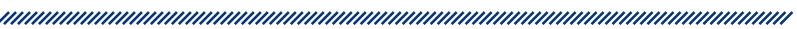

A multidimensional approach proved to be the best approach in solving the problem of compliance with the guidelines of hand hygiene by healthcare professionals. It involves the use of various strategies aimed at addressing obstacles to improving compliance with the proper hand hygiene and achieving longer-term behavioral changes. Many factors contribute to a reduced compliance rate. In developing countries, this is primarily a lack of necessary resources, and in developed countries it is the need for lifelong education and evaluation, and programs that will focus on evaluating proper hand hygiene techniques, and not just identifying opportunities for its implementation. Infections related to healthcare are a public health issue and as such do not bypass any healthcare institution. Prevention of healthcare associated infections is one of the main factors in ensuring the best quality of healthcare. The multimodal strategy of the WHO or its local modifications are proving to be effective methods in combating this problem. The space for further research presents itself in finding a better method of measuring compliance, technologically oriented solutions for the delivery and application of alcohol disinfectants, greater focus on evaluating proper hand hygiene techniques and providing longer-term training programs to achieve the best effectiveness of hand hygiene in healthcare workers.

\section{References}

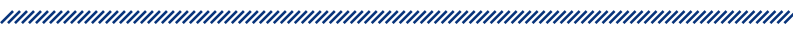

1. Haque M, Sartelli M, McKimm J, Abu Bakar M. Health care-associated infections - an overview. Infect Drug Resist. 2018;11:2321-2333. doi: 10.2147/IDR.S177247.

2. World Health Organization. Report on the burden of endemic health care-associated infection worldwide [Internet]. Geneva: WHO; 2011 [Accessed 15.4.2020]. Available from: https://apps.who.int/iris/bitstream/handle/10665/80135/9789241501507_eng.pdf;jsessionid=E 2399CB1B6774A7A9D4FA3A769C90757? sequence $=1$

3. Sax H, Allegranzi B, Uçkay I, Larson E, Boyce J, Pittet D. 'My five moments for hand hygiene': a user-centred design approach to understand, train, monitor and report hand hygiene. J Hosp Infect. 2007;67(1):9-21. doi: 10.1016/j.jhin.2007.06.004.

4. World Health Organsation. WHO guidelines on hand hygiene in health care (First global patient safety challenge clean care is safer care) [Internet]. Geneva: WHO; 2009 [Accessed 15.4.2020.]. Available from: https://apps.who. int/iris/bitstream/handle/10665/44102/9789241597906_ eng.pdf?sequence $=1$

5. Naikoba S, Hayward A. The effectiveness of interventions aimed at increasing handwashing in healthcare workers - a systematic review. J Hosp Infect. 2001;47(3):173-80. doi: 10.1053/jhin.2000.0882.

6. Erasmus V, Daha TJ, Brug H, Richardus JH, Behrendt MD, Vos MC, et al. Systematic review of studies on compliance with hand hygiene guidelines in hospital care. Infect Control Hosp Epidemiol. 2010;31(3):283-94. doi: $10.1086 / 650451$.

7. World Health Organization. A Guide to the Implementation of the WHO Multimodal Hand Hygiene Improvement Strategy [Internet]. Geneva: WHO; 2009 [Accessed 17.4.2020.]. Available from: https://www.who.int/ gpsc/5may/Guide_to_Implementation.pdf

8. World Health Organization. Hand hygiene technical reference manual [Internet]. Geneva: WHO; 2011 [Accessed 17.4.2020.]. Available from: https://apps.who.int/iris/ bitstream/handle/10665/44196/9789241598606_eng. pdf? sequence $=1$

9. Farhoudi F, Sanaei Dashti A, Hoshangi Davani M, Ghalebi N, Sajadi G, Taghizadeh R. Impact of WHO Hand Hygiene Improvement Program Implementation: A Quasi-Experimental Trial. Biomed Res Int. 2016;2016:7026169. doi: 10.1155/2016/7026169.

10. van Dijk MD, Mulder SA, Erasmus V, van Beeck AHE, Vermeeren JMJJ, Liu X, et al. A multimodal regional intervention strategy framed as friendly competition to improve hand hygiene compliance. Infect Control Hosp Epidemiol. 2019;40(2):187-193. doi: 10.1017/ice.2018.261.

11. Kolola T, Gezahegn T. A twenty-four-hour observational study of hand hygiene compliance among health-care 
workers in Debre Berhan referral hospital, Ethiopia. Antimicrob Resist Infect Control. 2017;6:109. doi: 10.1186/ s13756-017-0268-y.

12. Tschudin-Sutter S, Sepulcri D, Dangel M, Schuhmacher $\mathrm{H}$, Widmer AF. Compliance with the World Health Organization hand hygiene technique: a prospective observational study. Infect Control Hosp Epidemiol. 2015;36(4):482-3. doi: 10.1017/ice.2014.82.

13. Yawson AE, Hesse AA. Hand hygiene practices and resources in a teaching hospital in Ghana. J Infect Dev Ctries. 2013;7(4):338-47. doi: 10.3855/jidc.2422.

14. Kalata NL, Kamange L, Muula AS. Adherence to hand hygiene protocol by clinicians and medical students at Queen Elizabeth Central Hospital, Blantyre-Malawi. Malawi Med J. 2013;25(2):50-2.

15. Hand Hygiene Australia [Internet]. Melbourne: Auditing with the Five Moments for Hand Hygiene tool, 2011 [Accessed 18.4.2020.]. Available from: https://www.hha. org.au/audits/audit-tools/standard-5-moments

16. World Health Organisation. Clean Care is Safer Care. Tools and resources [Internet]. Geneva: WHO; 2009 [Accessed 19.4.2020.]. Available from: https://www.who.int/ gpsc/5may/tools/en/

17. World Health Organization. Ward infrastructure survey [Internet]. Geneva: WHO; 2010 [Accessed 18.4.2020. Available from: https://www.who.int/gpsc/5may/tools/evaluation_feedback/en/

18. Shen L, Wang X, An J, An J, Zhou N, Sun L, et al. Implementation of WHO multimodal strategy for improvement of hand hygiene: a quasi-experimental study in a Traditional Chinese Medicine hospital in Xi'an, China. Antimicrob Resist Infect Control. 2017;6:98. doi: 10.1186/ s13756-017-0254-4.

19. Allegranzi B, Gayet-Ageron A, Damani N, Bengaly L, McLaws ML, Moro ML, et al. Global implementation of WHO's multimodal strategy for improvement of hand hygiene: a quasi-experimental study. Lancet Infect Dis. 2013;13(10):843-51. doi: 10.1016/S1473-3099(13)70163-4.
20. Sax H, Allegranzi B, Chraïti MN, Boyce J, Larson E, Pittet D. The World Health Organization hand hygiene observation method. Am J Infect Control. 2009;37(10):827-34. doi: 10.1016/j.ajic.2009.07.003.

21. Huis A, Schoonhoven L, Grol R, Donders R, Hulscher M, van Achterberg T. Impact of a team and leaders-directed strategy to improve nurses' adherence to hand hygiene guidelines: a cluster randomised trial. Int J Nurs Stud. 2013;50(4):464-74. doi: 10.1016/j.ijnurstu.2012.08.004.

22. European Centre for Disease Prevention and Control. Summary: Point prevalence survey of healthcare-associated infections and antimicrobial use in European hospitals [Internet]. Stockholm: ECDC; 2013 [Accessed 20.4.2020.]. Available from: https://www.ecdc.europa.eu/sites/default/files/media/en/publications/Publications/healthcare-associated-infections-antimicrobial-use-PPS.pdf

23. Allegranzi B, Pittet D. Role of hand hygiene in healthcare-associated infection prevention. J Hosp Infect. 2009;73(4):305-15. doi: 10.1016/j.jhin.2009.04.019.

24. Koff MD, Corwin HL, Beach ML, Surgenor SD, Loftus $\mathrm{RW}$. Reduction in ventilator associated pneumonia in a mixed intensive care unit after initiation of a novel hand hygiene program. J Crit Care. 2011;26(5):489-495. doi: 10.1016/j.jcrc.2010.12.013.

25. Rothrock JC. Alexander's Care of the Patient in Surgery.14 ${ }^{\text {th }}$ Edition. USA; Elsevier: 2011. p.1276

26. World Health Organization. WHO guidelines for hand hygiene in health care (Advanced draft) [Internet]. Geneva: WHO; 2006. [Accessed 18.4.2020.]. Available from: https://www.who.int/patientsafety/information_centre/Last_April_versionHH_Guidelines\%5B3\%5D.pdf 


\section{SURADLJIVOST ZDRAVSTVENIH DJELATNIKA PRI PROVEDBI HIGIJENE RUKU U SPRJEČAVANJU INFEKCIJA POVEZANIH SA ZDRAVSTVENOM SKRBI - SUSTAVNI PREGLED LITERATURE}

\section{Sažetak}

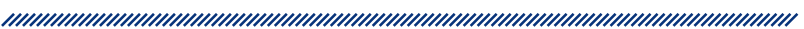

Uvod: Suradljivost zdravstvenih djelatnika pri provedbi higijene ruku predstavlja vodeći javnozdravstveni problem. Godišnje 37000 pacijenata umre od neke bolničke infekcije. Pojava bolničkih infekcija može se prevenirati, a higijena ruku jedna je od osnovnih mjera prevencije. Tijekom svakodnevne prakse ruke zdravstvenih djelatnika dodiruju neprekidni slijed površina, različitih tvari i neživih predmeta, stoga je pravilna higijena ruku prvi korak u sprječavanju prijenosa mikroorganizama između pacijenta, okoline i zdravstvenog djelatnika.

Cilj: Utvrditi suradljivost zdravstvenih djelatnika pri provedbi higijene ruku u skladu sa smjernicama Svjetske zdravstvene organizacije kroz sustavni pregled literature.

Metode: Sustavni pregled literature s pomoću smjernica PRISMA u bazi podataka PubMed u cilju pronalaženja članaka koji evaluiraju provođenje smjernica higijene ruku zdravstvenih djelatnika i stupanj suradljivosti prema smjernicama Svjetske zdravstvene organizacije.

Rezultati: $U$ obradu je uključeno šest članaka analiziranih na temelju kriterija dostupnosti cjelovitog teksta i godina publikacije između 2010. i 2020. godine. Stopa suradljivosti bila je najveća u studijama koje su primjenjivale multimodalnu strategiju higijene ruku Svjetske zdravstvene organizacije ili njezine modifikacije.

Zaključak: Višedimenzionalni pristup poput multimodalne strategije Svjetske zdravstvene organizacije ili njezinih lokalnih modifikacija pokazuje se kao najbolji pristup u rješavanju problema suradljivosti zdravstvenih djelatnika pri provedbi higijene ruku. Prostor daljnjim istraživa- njima otvara se u pronalaženju bolje metode mjerenja suradljivosti, tehnološki usmjerenom pronalasku boljeg rješenja za primjenu alkoholnog dezinficijensa, većoj usmjerenosti $k$ evaluaciji pravilne tehnike higijene ruku te osiguravanju dugoročnijih programa edukacije u cilju ostvarenja najbolje efikasnosti provedbe higijene ruku među zdravstvenim djelatnicima.

Ključne riječi: higijena ruku, Svjetska zdravstvena organizacija, stopa suradljivosti, zdravstveni djelatnici 